\title{
Legal Politics of Culture and Local Identity (Balinese) as Cultural Resources in Tourism Interaction in the Era of Globalization
}

\author{
I Wayan Wesna Astara ${ }^{1}$, I Wayan Budiarta ${ }^{2}$ and Putu Ayu Sriasih Wesna ${ }^{3}$ \\ \{wesna_astara@yahoo.com\} \\ Universitas Warmadewa, Denpasar, Bali-Indonesia
}

\begin{abstract}
Balinese culture has very important role in tourism activities. However one of Balinese cultures that begin to erode in this globalization era is Balinese language. Therefore, substantial measures to empower Balinese language are needed to protect this imperative Balinese identity. Researchers had conducted participant observations, unstructured interviews and document analysis or textual. The results of the study showed that Balinese people usually used Balinese language in daily conversation and religious ceremonial relations. In addition, Provincial Government formulated policy that mandate Balinese people to use traditional language as one of progressive step to preserve local identity. According to UUD 1945 (1945 Constitution), the constitution protects Balinese language and maintains local languages in each province as national cultural inheritance. Bali provincial regulation no 3 of 1992 stated that literacy and literature as legal umbrella to preserve Balinese Language from extinction. Therefore, strengthen legal protection for Balinese Language is crucial to do by using this language in local and international context.
\end{abstract}

Keywords: Balinese language; cultural politics; strengthening the identity in the globalization era

\section{Introduction}

Balinese culture is one of the traditional cultures in Indonesia. The existence of Balinese culture receives global appreciation. It turns out that Bali gets an exotic image such as the last paradise, the morning of the world, the island of God, and the island of thousand temples. It basically expresses the world's admiration for the uniqueness of Balinese culture [1]. Bali has an extraordinary characteristic compared to the regions in Indonesia. It has Balinese language and Balinese script that is Bali being a cultural capital to be empowered, developed and preserved. This was understood by the Dutch Colonial Government when it came to occupy Bali through Baliseering policy. Promoting the noble image of Balinese culture that had to be saved from the effects of modernization. The independence of Indonesian supports cultural also becomes a cultural capital to be protected in accordance with Article 32 of the 1945 Constitution stated that government promotes Indonesian National culture.[2] In the explanation of Article 32 of the 1945 
Constitution, the culture of the nation is the culture that arises as a result of the efforts of the Indonesian people as a whole [2].

The old and original culture that exists as cultural peaks in regional areas throughout Indonesia, counted as the culture of the nation. Cultural endeavors must lead to advancement in manners, culture, and unity. However these do not reject the new influences from foreign cultures that could develop, enrich and enhance the humanity of the Indonesian people. But after the amendment of the 1945 Constitution (the fourth amendment) article 32 section 1 declared that state promotes Indonesia's national culture in the midst of world civilization by guaranteeing the freedom of the people in maintaining and developing cultural values; Section 2 stated that state respects and nurture regional languages as national cultural wealth. Article 36, national language is Bahasa Indonesia. In addition, Balinese people formulated brilliant policies for answering the requirement of Balinese people in the context of globalization. [3] First, how does cultural politics in Indonesia protect the traditional inheritance in the context of Balinese language? Second, how to protect Balinese language particularly to empower commoners to use Balinese language in traditional villages in Bali. Both of these explain the phenomenon of Balinese culture (Balinese language) which is struggling against capitalism tourism industry. Those issues need to be addressed in order to harmonize Balinese Language as Balinese identity and adapt with foreign influence and culture. Additionally. These two issues are questions that are to be answered in the present study.

Qualitative method was applied in this study. According to Bogdan \& Biklen, preparing research designs in the qualitative method is temporary. In ongoing research, researchers are constantly adjusting the design to the research process and the realities that occur in the field. Researchers conduct participant observation, unstructured interviews and document or textual analysis. [4] In this study, the researcher is a key instrument and field note is applied in the process of collecting and analyzing data by using recording device. In this case the data analysis process was carried out since participant and non-participant observations, personal documents, official documents, pictures, photos, and open and in-depth interviews of the informants. Then the results were written in field notes. This research is transformative-participatory legal research with mix methods in moral and political characterized research. [5]

The research is collaboration of legal research and cultural studies. In cultural studies, it focuses on three approaches: a). ethnography which is associated with a cultural approach and emphasiszed on real experience; b). Textual approaches which tend to be taken from semiotics, post-rationalism, and Derida's deconstruction theory; c) reception study (reception study) which is electic theoretical roots. The important thing to be conveyed in this research is to reveal the dimensions of power and how that power influences the Balinese language to be sustainable in accordance with the authority possession.

\section{Results and Discussion}

\subsection{Indonesian cultural politics to preserve regional culture of Balinese Language}

Cultural politics in this case could be equated with policies of cultural sector in the study of Balinese culture. Policies could take to the form of laws in order to regulate culture [6]. Thus, law 
could serve as protection, mobilization and provides space for innovation in regional cultures in Indonesia [7]. Public policy according to Nugroho is political decisions made by public institutions. Public institutions are funded by public funds that are collected from public, either in the form of taxes, retribution, or other formally imposed levies [8]. This study focused on micro public policies that regulate the execution or implementation of the above policies that are commonly accepted including the Bali Province regional regulations.

According to Gramsci's Hegemony Theory, in the political context of the protection of the State against Regional Languages (Balinese) could be explained that hegemony is as cultural leadership that is carried out by the ruling class. Hegemony is not "the use of force from the ruling class", which is used by the legislative or the executive, but it is realized through policy intervention. The state embodies the policy through the executive and legislative institutions or the People's Consultative Assembly (MPR) by forming or amending the 1945 Constitution as contained in Article 32 section 2. Furthermore, the Regional government issued Bali Provincial Level I Regulation Number 3 of 1992, concerning Balinese Language, Literacy and Literature in terms of fostering, developing and preserving Balinese Language, Literacy, literatures and culture [3].

The emergence of this public policy is a response to the concerns of educators, experts, community leaders, writers, religious leaders and others that believe the Balinese language would extinct if it is not handled thoroughly. The process of establishing a law that is oriented towards defending the needs of the local community, especially in Balinese, is an urgent need to defend cultural rights and local wisdom. This is related to the norm of necessity to humanize the norms of reality that produce situations that justify Balinese language to serve as virtues in constructing Balinese identity. [9]

State protection against Indonesian culture in this context Regional languages (Balinese) has been guaranteed in the Constitution of Republic of Indonesia 1945 Constitution (fourth amendment) Article 32 Section 1 explained that

States promotes Indonesia national culture in the middle of global civilization by guaranteeing the freedom of society; Section 2 declared States respects and nurture local languages as national cultural inheritance. Furthermore, recognition in the Law of Republic Indonesia number 24 of 2009 concerning Flags, Languages and State Symbols and National Anthem, Article 6 number 6 , Local Language is a language for generations by Indonesian citizens in region. The Unitary State of the Republic of Indonesia; Article 1 Section 2: Language of the Unitary State of the Republic of Indonesia hereinafter referred as Indonesian Language is the official National Language. Article 28, Indonesian language must be used in official speeches of the President, Vice President and other State officials who are confined inside or outside the country. Article 32 Section 2 Indonesian languages could be used in international forums abroad. Article 38 Section 1 Indonesian language must be used in general signs, road instructions, public facilities, banners and other information tools which are public services; Section 2 the use of Indonesian Language as referred to in Section 1 may be accompanied by regional languages and/or foreign languages. This has been done through using Balinese language in traditional Balinese wedding activities, traditional village competitions, traditional village meeting, custom ceremony and other activities (interview with the Head of Traditional Village of Celuk Sukawati, November 22, 2017).

Strengthening the protection of the Balinese language as a regional language used by Balinese and other speakers, which is maintained and developed as a bearer of Balinese culture and 
Balinese society (Article 1 letter (f) Level I Regional Regulation of Bali Provincial number 3 of 1999 concerning Language, Literacy and Balinese Literature). In the explanation of Level 1 Regional Regulation of Bali Provincial Number 3 of 1992 concerning Balinese Language, Literature and Literature, that in the Broad Guidelines of State Policy (GBHN) of 1988-1993 and the implementation in the basic pattern of Bali Province Regional Development in the year 19881993 which was included in the Bali Provincial Level I regional regulation number 9 in 1988 formulated that Regional Languages and literature needed to be continuously fostered and preserved in order to develop and enrich Indonesian vocabulary and literature and national cultural treasures as an element of the nation's personality [3]. The issuence of the Bali Regional Regulation Number 3 of 1999 is a legal function of service, which is to serve in saving Balinese Language, Literacy and Balinese Literature from extinction [10]. In this case, it is necessary to practice Balinese language in the reality of society which, despite being battered by tourism, requires tourism to use foreign language. What if in guiding also insert Balinese language into an explanation of Balinese culture and at the same time translate into foreign languages. This can be found in the calling of passengers at Ngurah Rai Airport Denpasar Bali in addition to use Indonesian, English as well as Balinese Language (researchers departing for Vietnam on August 26,2018 ) directly heard the use of Balinese in calling the passengers.

This policy reflects that the Bali Provincial Government can make a cultural policy that is obliged to insert Balinese Language to be applied inbesi guiding workers on the island of Bali as an aspired law (iusconstituendum). The Provincial Government of Bali can make Regional Regulations that require in guiding the tourist besides speaking English also using Balinese. This is related to the Bali Cultural Tourism Concept based on Bali Provincial Regulation No. 2 of 2012 concerning Balinese Cultural Tourism. If Bali consistently applies this Regulation, in accordance with Article 3, the culture tourism of Bali aims to: (a) preserve Balinese culture imbued with Hindu religious values; the understanding of preserving Balinese culture should also preserve Balinese Language in tourism activities by introducing Balinese Language in tourism activities in explaining Balinese culture which is then translated into Foreign Languages. In line with Article 4, Bali Cultural Tourism Development is directed to: (c) preserve Bali's natural environment as a basis for sustaining community life and Balinese culture in a sustainable manner, (preservation of Balinese Language in the practice of tourism needs to be realized in praxis value). In the context of reciprocal relations between tourists and owners of Balinese culture which is explained in Article 27 Section (2) each tourist must: (a) respect religious norms, customs, culture and values that live in the local community; (b) maintain and preserve the environment; (c) participate in maintaining environmental order and security; (d) do not commit acts that violate decency. In the implementation of the Balinese Language policy as a local language in the Province of Bali in preserving Balinese culture there needs to be a cultural strategy (culture as a plan) given that the onslaught of capitalist culture that enters life can synergize in local values in a global context [11]. The pressure of global capitalism will affect the values of Balinese culture in the roar of tourism (global capitalism) and local values need to be adapted in tourism activities by adding Balinese Language (combined, reconstructed and deconstructed) according to the interests and needs of Balinese culture.

Top of Form Bottom of Form 
The cultural politics of Balinese language for the Province of Bali is to foster, develop and preserve Balinese Language, Literacy and Literature as a whole (ie includes Balinese Language, Balinese Script and Balinese Literature and Kawi Language), and simultaneously establishes its formal position and function as the basic asset of development Bali area beside Indonesian. Obviously here is the government's duty to advance regional culture that lives in areas not to become extinct. Article 6, Section (1): The Balinese Language, Literature and Literature Development Body is an agency tasked with carrying out guidance and formulating programs for the maintenance, assessment, development and preservation of Balinese Language, Literature and Literature. Article 7 states that in an effort to increase the use of Balinese Literacy and Literature implemented through formal and non-formal channels. In the explanation stated that the formal pathway is through education from elementary level up to university. Non-formal pathways are through counseling, upgrading, training programs, art festivals and competitions. [12]

Bali have a position of Islamic society which is often called Wong Sunantara. Wong Sunantara, which comes from Bugis, Malay, Javanese, Madurese and Banjar people who generally adhere to Islam. They were called Bali Islam or Bali Selam, after adapting and staying long enough in Bali and mingling with the local community. Muslims or Bali Selam are also well received in the integrity of society. They are easy to adapt in the local community by using Balinese as a language of communication in everyday life, especially in old Islamic communities such as in Singaraja, Java Banjar, Bugis Village, Pegayaman (Buleleng), Kepaon, Serangan, Suwung (Denpasar), Bugis Village (Tuban), Angantiga (Badung), Kampung Gegel, Kampung Jawa Kusamba, and Toya Pakeh (Klungkung) and in several villages (around 26 in number) in Karangasem. Even the social system in Bali is known for its Nyama Selam (Muslims brothers) by the castle or Nyama Bali community. With recognition as Nyama Selam for Muslims, it is an adhesive to establish a life together in the midst of Balinese society. [13]

\subsection{Protection of Balinese Language, especially in the form of Balinese language empowerment in traditional villages/Pakraman in Bali}

Balinese language is the local language used by Balinese and other speakers, which is maintained and developed as a development of Balinese culture and Balinese society (Article 1, paragraph (f) Bali Provincial Level Regulation No. 3 of 1992 concerning Language, Literacy and Balinese Literature). Furthermore, the traditional village or Pakraman village as a unit of customary law in the province of Bali which has a unity of tradition and social order of life of the Hindu community for generations in a bond of kahyangan three or kahyangan village that has a certain area and own assets and has the right to take care of the household itself (Article 1 paragraph (4) Regional Regulation of the Province of Bali concerning the village of Pakraman Number: 3 of 2001). [12] Pakraman Village also serves as a locus (place) for resolving disputes outside the court (non litigation). The settlement of the dispute is mainly concerning civil law issues. This model of the settlement of the conflict is called ADR (Alternative Dispute Resolution). For the Bali region the role of Indigenous Bendesa / Prajuru Adat or Kelian Banjar Adat / Prajuru Banjar (Tradtionals Leaders) in alternative dispute resolution. Traditionally these officers have been used to solve problems that occur in their environment (Rai Asmara Putra, Dw N, 2010: 1-25). In settling disputes in Pakraman Village or in Banjar Adat / Pakraman against disputing manners by using Balinese Language (Interview with Drs. I Wayan Mendra, M.Sc., Bendesa Adat Tuban, on December 11, 2017). 
One of research in Bali, said that Balinese language was marginalized due to the ideology of tourism capitalism. Cases that occurred in Ubud and Kuta in foreign languages have shifted Balinese language in business interaction, namely the language used in Balinese language, interfering with Indonesian, even in foreign language. Awareness of Balinese Indigenous Peoples to preserve Balinese Language can be clearly known in the activities of Pawiwahan (Marriage) based on Hinduism, paruma (meeting) $\mathrm{n}$ traditional villages, paruman (meting) Banjar, traditional village competitions, customary activities, religion and culture. Balinese language has social meaning for business interaction, there is a combination of language in tourism activities. It turns out that in preserving Balinese Language is not only from the community of traditional villages/banjar adat, but even tourists in Ubud village have learned Balinese, they are chatting with Balinese using Balinese. [14]

The cultural practice of using Balinese language is the phenomenon that Balinese language will "extinct" so that the policy of the Regional Government of the Province of Bali appears. Form of micro policy to provide legal assurance and certainty that Balinese Language has been protected. Legal certainty and protection in the form of regional regulations can be analyzed with Derrida's Deconstruction theory as a figure of poststructuralism. Deconstruction done by Derrida is rejection /dismantling of logocentrism or phenocentrism. Article 7 of Bali Province Regional Regulation Number: 3 of 1992 concerning Balinese Language, Literacy and Literature is carried out through formal and non-formal channels. The law made is claimed as if a representation of reality and legal truth. According to Foucault's Discourse, the law states that every legal discourse cannot be separated from the operation of certain powers (knowledge) and social relations in both, which results in what is called truth and justice. Truth cannot be separated from power; and do not care whether the truth product represents the final truth or not. Legal truth is displayed in the form of imaging. [3]

In Balinese communication with tourists the ideology of capitalism that preserves the choice of using language. In business activities the use of Balinese Languages, Indonesian and even foreign languages (English). The role of English in the tourism business can be seen from the informant I Wayan Arnata (36 years) a Security Officer at Kuta Art Market (Kuta beach side) from Legian Kelod Banjar (Legian-Kuta) said that Balinese Language was collaborated with English when beggars were found begging on Kuta beach. The use of two languages or more often occurs in tourism areas such as Bali.

\section{Conclusion}

That the Balinese language as a Mother Tongue in the Province of Bali, found its identity with the existence of state hegemony, in the form of a legal product by changing the 1945 Constitution especially concerning the existence of Article 32 Section (2). In the context of state governance Article 32 Section (2), whose derivatives are by the Provincial Government of Bali issued Regional Regulation Number: 3 of 1992 concerning Balinese Language, Literacy, and Literature. Thus, the certainty, legal protection of the Balinese language and the preservation of the Balinese Language has the force of law. Historically Balinese language is a unifying Balinese Hindu tribe. However, Balinese is also a social language and as an adhesive for various ethnic groups in Bali 
such as Moslem Bugis ethics, Javanese ethnic Muslims, Chinese ethnic Kong Fu Tsu, and others. Even in Balinese religious, custom and cultural activities, Balinese Language is used by Indigenous leaders in Bali in resolving customary (adat) offenses. Even Balinese is a cultural tool and transformation occurs because it enters into the realm of tourism language. This is the power relations of Balinese Language as a strength, Balinese identity and the uniqueness of Bali as a tourism destination.

\section{References}

[1] Pastika, I, W, et all.: Peta Jalan Penelitian Fakultas Ilmu Budaya Universitas Udayana 2017-2021, Udayana Univ. Press (2017)

[2] I. Government, First, Second, Third and Fourth Amandements of 1945 Constitution Republic of Indonesia

[3] G. of B. Province, Regulation of Level I Area of Bali Provincial about Language Bahasa. Indonesia: 3 of 1992 (1992)

[4] Alsa, A.: Pendekatan Kuantitatif dan Kualitatif Serta Kombinasinya dalam Penelitian Psikologi. Yogyakarta: Pustaka Pelajar (2004)

[5] Susanto, A, F.: Penelitian Hukum Transformatif-Partisipatoris Fondasi Penelitian Kolaboratif dan Aplikasi Campuran (Mix Method) dalam Penelitian Hukum. Malang: Research law Setara Press (2015)

[6] Harbour, J and Wilson, J.: Political management and local government: The views of local authority chief executives, Public Money Manag, vol. 23 (1). pp. 51-58 (2003)

[7] Astara, I, W, W.: Pertarungan Politik Hukum Negara dan Politik Kebudayaan, Otonomisasi Desa Adat di Bali. Denpasar: Udayana University Press (2010)

[8] Fender, J and Watt, P, A.; Control the Level of Local Authority Expenditures ?, vol. 23 (2). pp. 265-285 (2002)

[9] Kusumohamidjojo, B.: Teori Hukum Dilema antara Hukum dan Kekhasan. Bandung: Yrama (2016)

[10] Picard, M.: Bali Pariwisata Budaya dan Budaya Pariwisata. Jakarta-Paris: Jean Couteau and Warih Wisatsana (2006)

[11] Van Peursen, C, A.: Teori Kebudayaan Van Peursen (1976) [Online]. Available: http://amarcivicus.blogspot.com/2013/05/teori-kebudayaan-van-peursen.html. [Accessed: 21-Nov-2018].

[12] Gubernur Provinsi Bali, Peraturan Daerah Provinsi Bali Tentang Bahasa, Aksara dan Sastra Bali. p. 11 (2018)

[13] Ridho, M.: Inter-Religious Relationship Between Hindus And Muslims, Harmoni, vol. 16 (1). pp. 38-56 (2017)

[14] Narrottama, N.: Religion As The Last Fortress Of Bali Cultural Tourism, in International Conference on Emerging Tourism Destinations, p. 10 (2016) 